\title{
地域協働型インフラ管理の実装に向けた 行政と地域住民の役割分担に関するモデル分析
}

\author{
富田＼cjkstart敬之 1 ・大野 沙知子 2 ・杉浦 聡志 3 ・高木 朗義 4 \\ 1学生会員 岐阜大学大学院 工学研究科社会基盤工学専攻（†501-1193岐阜県岐阜市柳戸1-1） \\ E-mail:t3121018@edu.gifu-u.ac.jp \\ 2正会員 岐阜大学 特任助教 工学部附属インフラマネジメント技術研究センター \\ （テ501-1193岐阜県岐阜市柳戸1-1） \\ E-mail:satiko@gifu-u.ac.jp \\ 3正会員 岐阜大学 研究員 工学部社会基盤工学科（†501-1193岐阜県岐阜市柳戸1-1） \\ E-mail: sugi_s@gifu-u.ac.jp \\ 4正会員＼cjkstart岐阜大学教授工学部社会基盤工学科（テ501-1193岐阜県岐阜市柳戸1-1） \\ E-mail: a_takagi@gifu-u.ac.jp
}

\begin{abstract}
財源，技術者の不足する状況下において，すべての道路を技術者が管理することは困難である．地域住 民が参加することで管理のすきまを埋めることや住民目線での社会資本の損傷を発見することにつながり， 制約の中できめ細かい管理ができる可能性がある。本研究では, 地域住民を道路管理の一主体とし, 技術 者と連携する地域協働型インフラ管理について，住民と技術者の分担を考察するため，それぞれのコスト とリスクから社会的費用を定義する。社会的費用を構成する要素として，地域住民によるインフラ管理費 用，行政によるインフラ管理費用，道路管理における交通事故リスクをモデル化する. 簡易的なシミュレ ーションの結果から, 最適な地域住民の点検回数と技術者の点検間隔について挙動を確認し, 社会的費用 を最小化する条件について考察を行った。
\end{abstract}

Key Words :cooperative road facilities management, road patrol, social cost, resident participation

\section{1. はじめに}

現在，我が国では社会資本の維持更新が社会的な課題 であり，道路は社会資本の 3 割を占め，その多くを予算 や技術者の不足する市町村が管理している.このような 状況のもと, 道路や橋梁といった構造物の日々進行する 劣化に対して, 損傷を早期発見するための日常点検の仕 組みを提案することが重要であり, 住民参加や地域協働 に期待がある ${ }^{1)}$. 地域住民が参加することで管理のすき まを埋めることや住民目線での社会資本の損傷を発見す ることが想定され，制約の中できめ細かい社会資本管理 ができる可能性がある．このような考えのもと，筆者ら は，地域住民を社会資本管理の一主体として位置づける 地域協働型インフラ管理を提案してきた ${ }^{23)}$.

地域協働型インフラ管理においては，例えば，地域住 民はポットホールや道路障害物の点検・報告，清掃作業 などに参加することが役割となる．行政は従来の定期的 な点検や補修作業に加え, 地域住民の活動を踏まえた計
画，サポートを行うことが必要となる．その結果，技術 者不足により従来の管理方法では技術者の管理が行き届 いていない道路施設であっても，地域住民が点検の役割 を担うことでリスクの縮减が期待できるだろう。一方で, 地域住民と専門家の管理能力の違いから, 高い頻度で点 検を行っても効果が得られないといった負の影響もある だろう．地域協働型インフラ管理の実装に向けては，地 域住民の能力や参加することによるコスト, リスクの関 係から, 行政と地域住民の役割を具体化し, 社会的な影 響を示すことが必要である.

本研究では，社会資本のうち，住民が管理に比較的参 加しやすい道路舗装を対象とし, 容易に発見しやすいポ ットホールを地域住民と技術者が点検することを想定し た数理計画モデルを構築する. このモデルでは地域住民 と行政のコスト，リスクから構成される社会的費用を定 義する．簡易的なシミュレーションから，地域住民が協 働した場合の社会的費用の算出を行い，モデルの挙動確 認を行う。技術者の点検の間に地域住民が点検を実施す 
ることを想定した分析をすることで，社会的費用が最小 化になる条件を示し，地域住民と技術者の役割分担につ いて考察する.

\section{2. 既往研究の整理と本研究の位置付け}

本章では，まず，既往研究の整理から，本研究の位置 らけを示寸. 次に, 地域協働型インフラ管理への住民の 参加の考え方や住民の役割の可能性について事例を整理 し，インフラ管理への住民参加の現状と課題について示 寸. そして，本研究の基本的な考え方を示す.

\section{(1) 既往研究の整理}

道路管理の点検方策に関する研究として，貝戸ら ${ }^{4} は$ は, 道路障害物の発生過程をモデル化し, 道路点検の最適巡 回間隔の分析を行っている. そして，放置時間の増加に よるリスク増大から，リスクを一定值以下にするために 最適な点検頻度を求める方法を提案している. 小濱ら 5 は, 道路障害物発生数及び苦情発生数をリスク管理指標 としている，そして，障害物及び苦情の発生と巡回費用 のトレードオフの関係から，期待総費用を最小化する最 適道路巡回モデルの定式化を行っている. 道路管理にお けるリスクは，発生してから放置される時間によって変 化し, 点検頻度の増減から縮减について考えることがで きる. 本研究では，一定の間隔で実施される技術者の点 検の間を地域住民が埋めることを想定したモデルを構築 する．これは，すべての道路舗装の日常点検を行政が実 施することには限界があり，地域住民が参加することで 管理のすきまを埋めることや住民目線での社会資本の損 傷を発見することを意図している. 行政の点検に加え, 住民参加を考慮する場合, 地域住民による点検の頻度と 報告率を考慮する必要がある.

地域協働型インフラ管理に関する研究として, 大野 ${ }^{2)}$ は従来の管理の仕組みを役割や連携から見直した先進的 な事例の分析を行い，適切な地域協働型インフラ管理の 枠組みを提案している。 ここでは, 関係主体の役割や連 携方法を示している. 住民参加においては, 地域活動に 積極的な住民をインフラ管理の担い手として位置付ける ことや, インフラ管理を地域の活動として創出すること が有用であるとする．岐阜県中津川市のインフラに関す る市民と行政の連携の取り組みに関する研究 ${ }^{3)}$ では, 地 域協働の範囲や協働を成立させる要件について示さてい る. 管理量と管理能力がかい離する中で, 地域協働でイ ンフラを管理する必要性は一定の範囲において有用であ ると考える.一方で, 地域協働型インフラ管理の社会実 装のためには，地域住民が役割を担うことによる技術者 の業務への影響や地域社会への影響を示寸ことが必要で
ある。

\section{（2）地域協働型インフラ管理の事例}

インフラ管理への住民の参加の取り組み方は様々であ る.ここでは, 一例を取り上げ, 取組の特徵と地域住民 が担う役割について整理する.

\section{a) 道守}

地域にあるインフラを地域で守る仕組みとして，長崎 大学工学部インフラ長寿命化センター(ILEM) は, 平成 19 年から道守といらインフラメンテナンスに関わる専 門知識を有する技術者を育成するプログラムを実施して いる，道守の取り組みでは，建設事業に従事する技術者 を対象とした道守・特定道守・道守補と，一般住民を対 象とした道守補助員の講座を設けているの。一般住民を 対象とした道守補助員の講座は, 主にコンクリートや鋼 橋, 道路・斜面の変状など, メンテナンスに関わる基礎 的な知識を習得させることを目的としている.ここでは 点検結果を報告する道守シートの書き方や提出方法につ いても学習する. 受講者は講義終了後に, 道守補助員の 資格が付与され，日常生活の中で発見したインフラ構造 物の異変を管理者に通報する役割を担う。ILEM が一般 住民をインフラ管理の担い手として位置づけた目的は, 管理者が事業として定期的にインフラの点検を実施する 一方で，住民は日々の生活の中でインフラに触れている ことから, 異変に早く気づくことができると考えたため である. 異変の早期発見が可能となることで, 各種構造 物の長寿命化につながることを期待している. なお,

ILEM の取り組みは，より高度な技術をもつ道守，特定 道守, 道守補と道守補助員を連携させることにより, 早 期で高度な対応が可能となるような体制の構築が期待で きる.

b) 社会基盤メンテナンスサポーター(MS)

岐阜県では平成21年度より，地域の道路を地域で見守 る制度として，「社会基盤メンテナンスサポーター」

（以下，MSをする）を実施している78).MSは岐阜県民 を対象として公募され, 道路施設などの点検に必要な知 識を習得する講習を受講した後に委嘱される.MSは安 全で快適な道路の確保を目指し, 危険個所の早期発見や 早期修繥が実施できるように担当区域を決めて簡単な点 検や情報提供を行う。管理者は，MSから道路損傷等の 情報提供があった場合は対応結果を必ずMSへ報告して フィードバックをすると共に, 年1回のフォローアップ 研修を開催することで, 持続的な制度となるよう配慮し ている. MSの活動に対する支援として，MS委嘱元であ る岐阜県は，ボランティア保険に加入する手続きを行う こと及びその保険料を負担すること, 帽子や安全べス卜 等活動に必要な物品を支給することを決めている.

\section{c) 福島県における橋守事業}


岩城は，協㗢による橋守事業を報告している9). 財政 難などの理由から市町村が管理する橋梁では劣化に対応 する補修等が困難であるが，地域住民の手によって側溝 の掃除などの簡単な作業を行うだけでも，橋の延命化に は十分な効果があるとしている ${ }^{10}$. 4つの市を対象とし て，それぞれの地域に適した形での住民参加を進めてい る. 地域住民は輪番制での排水柝の清掃や堆積土砂の撤 去, 防護椢の塗装, 美化(植栽)といった作業が主な業務 となる. 橋守のモデルケースとして, 規模の大きな市で は行政職員やエンジニアを中心とした事業を構築してい る. また，従来から村民が働き手となっている地域では 村道のコンクリート舗装の新設や, 補修作業も地域住民 が実施している例もある.

\section{d) マイレポはんだ}

携帯端末を活用し，誰でも気軽にインフラの管理に参 加できる仕組みも増えている. 愛知県半田市では, スマ ートフォンアプリFix my street ${ }^{11)}$ 利用した「マイレポは んだ」を市民に提供している ${ }^{12}$. これは，道路の俻没な どの異常を発見した地域住民がスマートフォンから写 真・場所・状況を投稿し，市の担当者が投稿内容を見て 対応を行う仕組みになっている.これは地域住民にイン フラ管理への参加の機会を増や寸ことで, 地域住民のイ ンフラへの関心を高めるきっかけとなることを期待した ものである. また，管理者は，地域住民目線での点検を 促すことで, 従来の管理体制では目が届かない道路上の 異常を早期発見することを期待している.

\section{（3）インフラ管理への住民参加の現状と課題}

既往研究及び事例の整理から，住民参加を考える上で 課題となる要因について整理する.

大野は，地域住民がインフラ管理に参加寸る要件とし て，住民が担うべき範囲を設定する必要があると指摘す る3．例として原材料支給という制度について考えてみ よう。これは，管理者が住民一道路等の小規模な整備, 補修を許可するとともに材料を支給し，住民が施工する 制度である. 地域住民の有志で施工されるため, 安価に 整備ができることがメリットである．しかしながら，住 民の能力で可能な範囲の工事しか実施できない. また, 工事の精粗については保証されていない，そのため，コ ストメリットを重視して無秩序に原材料支給制度を拡大 すれば，管理対象全体の安全性は確保できない，したが って，ある一定レベル以上の作業は少なくとも管理者， あるいは管理者に委託された専門家の関与が必要になる。 以上より，インフラ管理における住民参加は，住民の参 加コストや能力に応じて適用寸る範囲を検討寸ることが 必要であると考える.

半田市の事例では地域住民が手軽に損傷等を報告でき るメリットがある一方で，MSや道守補助員のように基
礎的な知識も持たない一般の住民が投稿するため，必ず しもインフラの異常が報告されるとは限らない，市民一 システムが認知され, 多数の報告が得られるようになっ た結果，管理者はその寸心゙てについて，有益な情報であ るか選別する作業時間が発生し，本来行うべき業務が実 施できないなど，協働を目指した取り組みがかえって現 状の悪化につながることも想定される.このことからも， 地域住民の能力, 専門家の能力を考慮して, 社会的に最 適な住民参加の方法や役割分担を提案することは重要で ある。

\section{（4）本研究の基本的な考え方}

日常的にインフラに接する機会を持つ地域住民がイン フラ管理に参加することで，予算や人員により制約され た行政の管理能力を補完できると考える. 一方で，十分 な知識を持たず，任意で参加する地域住民の点検能力， 精度とリスクの関係を鑑みれば，地域住民が点検時間を むやみに投入しても十分な効果は得られない. すなわち, 行政と地域住民は適切に役割分担することが必要である.

インフラ管理への住民参加の方法は多く考えられるが, 本研究は道路舗装のポットホールへの対応を対象とする. 舗装は日常生活する中で目にする機会が多く, 異常であ るポットホールは容易に発見できるため, 住民が参加し やすい. ポットホールへの対応は一般的に管理者が定期 的に点検を実施し，ポットホールが発見されたときに補 修する. 管理者の点検は1週間から2週間に1度などの頻 度で害施されることが多い. よって, その期間にポット ホールが生じれば，事故を誘引するおそれがある，その ため，管理者による点検の間の期間を地域住民が補完す るように点検を実施し，早期にポットホールへの対応を 実現するような協働の方法を考える。この条件において ポットホールの生起をリスクとして捉え，管理者の点検 費用や住民の供出する時間を加味した社会的費用を最小 化するような役割分担について求める数理計画モデルを 構築する. また, 構築したモデルの挙動を仮想的な試算 により確認する.

\section{3. 地域協働型インフラ管理の数理計画モデル}

本章では，まず本研究で構築するモデルの目的関数を 示寸. 次に, モデルの条件設定について示し, 本研究に おけるリスクの考え方について整理する. そして, 社会 的費用を構成する要素の算出方法について示寸.

\section{(1) 目的関数}

従来の道路舗装管理ではポットホールや落下物による 道路事故を防止するために，道路管理者が技術者に委託 
し，点検が実施される．技術者による点検の間隔が長く なれば，ポットホールが発生した場合に放置される期間 が長くなり，累積のリスクは増大寸る，言い換えれば, 技術者の点検頻度が高くなるほどリスクは低減できる一 方で，管理者のコスト負担は大きくなる．技術者による 点検の合間に地域住民によって点検が行われれば，地域 住民によってポットホールが報告され，補修されること でリスクは縮减できる，しかしながら，住民による協働 も住民が余暇時間を供出するため, 点検頻度が高くなる ほど地域住民が供出する時間価値は増大寸る．したがっ て，点検頻度とリスクはトレードオフの関係にある．以 上のことから本研究で目指寸地域協働型インフラ管理の 数理計画モデルは地域住民によるインフラ管理費用 $U$, 行政によるインフラ管理費用 $G$, 道路管理における交通 事故リスク $R$, これらの1週間における平均值の総和で 定義される社会的費用(以下， $S C$ とする)を最小化する問 題とする.

$$
\min S C=U+G+R
$$

\section{(2) モデルの条件設定}

本研究では，一定の間隔で実施される技術者の点検の 間に，地域住民による点検が行われることを想定する. 以下にモデルが想定する条件について述べる，ある道路 区間において，一定の間隔 $T$ (週)で技術者による点検が 行われている状態を考える. 行政による点検の実施者は 職員，委託された企業の技術者が考えられるが，ここで は区別しない. 本研究で設定するポットホールの生起と 点検の関係を以下に整理する.

a)この道路区間では, 毎日平均して $P_{1}$ の確率でポット ホールが発生する.

b) ポットホールが発生していれば，事故の原因となり， 残存する限り交通事故リスクが発生する.

c) 技術者によって点検が行われたときには，発生した ポットホールはすべて補修され，リスクは0になるとす る.

d) 技術者による点検のほかに毎日 $P_{2}$ の確率で地域住民 による点検が行われる，このとき，住民は $P_{3}$ の確率で ポットホールを発見し，道路管理者に報告する.

e) 住民により報告されたポットホールは即時に補修さ れ，リスクが0になる.

定義した確率について説明を加える． $P_{1}$ は道路性状調 查の結果とポットホールを補修した履歴データなどから 統計的に分析した值を想定寸る.ここではこの值が年平 均確率などで与えられ，時系列で変動しないと仮定する。 つまり， $P_{1}$ は一定である.

これは，住民と専門家の点梌頻度を考慮した年間の管 理計画を立案することを想定するためである．長期的な 計画策定であれば，舖装の劣化が進行し， $P_{1}$ が変化す

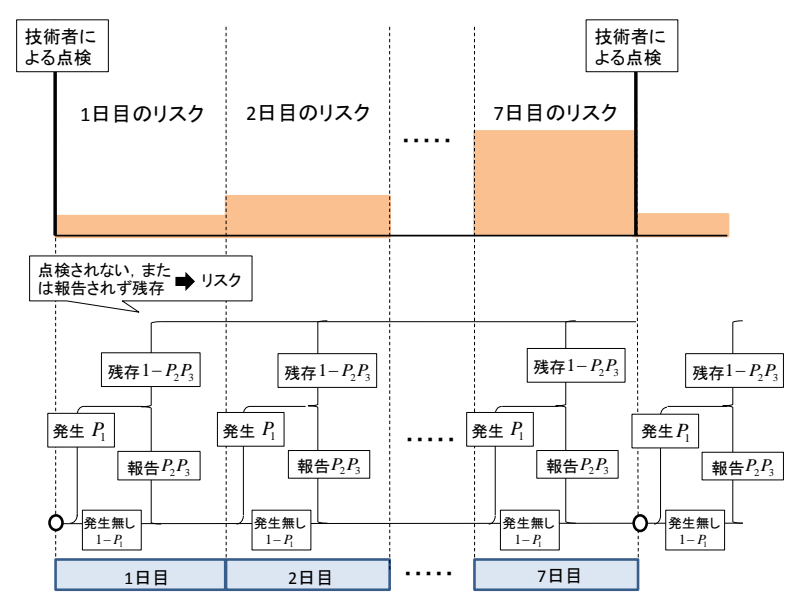

図-1 点検状況のフロー(技術者が 1 週間隔で点検する場合) ることも考えられるが，年間計画のように 1 年間程度の 想定であればほぼ一定としてみても大きな問題はないと し， $P_{1}$ を設定している.

住民による点検が実施されない，または点検で見逃さ れ報告がされなければ, $1-P_{2} P_{3}$ の確率でポットホール は翌日に残存する. 上記の設定に基づくとポットホール が残存したとき, 翌日にも $P_{1}$ の確率でポットホールが 生起する.一般的な舗装の劣化では, 舗装全面が劣化す ることはまれであり, 局所的なひび割れが一部に生じ, ポットホールの生起につながる. したがって, 想定する 単位区間が路面性状調査最小単位である $20 \mathrm{~m}$ など短いと き, ポットホールが生起しうる点は狭い範囲となる. ポ ットホールが狭い範囲に複数生起したときの交通事故の リスクと1つ生起したときのリスクの差は明らかでない. ポットホールの数だけでなく, 1つあたりのポットホー ルの大きさも事故リスクへ影響するだろう。このように 現状ではポットホールと事故リスクの関係に関する知見 が十分に蓄積されていない，そのため，本モデルで設定 するポットホールと事故リスクの関係の厳密に表現する ことは今後の蓄積を待って更新するとして，ここでは住 民協働のモデル開発に主眼を置いて仮定をおく．ポット ホールが狭い範囲に複数生起するときと1つ生起すると きでは事故リスクが同じであるとする. このとき, ポッ トホールの生起は個数に関わらず生起しているから゙うか のみを確率で表現するのと等価である。したがって，本 モデルでは検討対象とする区間・期間において, 複数個 のポットホールは同時に存在しないと仮定し，ある日の ポットホールが残存したとき, 翌日のポットホールがあ る確率は $P_{1}$ と無関係に $1-P_{2} P_{3}$ となる.

$P_{2}$ は地域住民の人数や意識, 道路環境などの条件に よって決定される， $P_{3}$ は地域住民の習熟の度合いによ って決定される確率である.

ある日に技術者の点検が行われたとき，次に技術者に よる点検が実施されるのはT週後となる，技術者の点検 頻度が低い，すなわち間隔が長いほどポットホールが残 
存する期間は長くなるため，累積のリスクは増大寸る. 以上の点検の状況のフローと累積リスクの考え方を整理 し図-1に示寸.

\section{(3) モデルに用いる変数の設定}

地域住民によるインフラ管理費用Uは，1 週間中に行 われる地域住民の期待点検回数 $x, 1$ 回あたりの点検に 供出するコストCの積で定義する．地域住民の点検によ るコストは，点検を行うことで消費する余暇時間の価值 とする

$$
U=x C
$$

行政によるインフラ管理費用 $G$ は，技術者による 1 回 の点検かかる費用を，1 週当たりに平均した值で定義す る.

$$
G=\frac{1}{T} C^{\prime}
$$

ここで, $T$ : 単位間隔中の週数(週), $C^{\prime}$ : 技術者が 1 回 点検する費用 $($ 円)である.

技術者，地域住民による点検の未実施，あるいは報告 されなかったことによりポットホールが残存するとき， 事故が生じる、ポットホールが残存している条件下にお ける交通事故発生による期待被害額を $D$ (円/日) とする. 1 日あたりのリスクはポットホール残存確率と期待被害 額の積で表現する. 前述の整理に基づいて複数個のポッ トホールが同時に存在しないと仮定して，技術者の点検 から $n$ 日目にポットホールが残存する確率は，(4)式で表 現できる.

$$
\sum_{i=1}^{n} P_{1}\left(1-P_{1}\right)^{i-1}\left(1-P_{2} P_{3}\right)^{i}
$$

道路管理における交通事故リスクRは，T週中の日数 分のリスクの累積值を， 1 週間あたりに平均した(5)式で 定義する.

$$
R=\frac{1}{T} \sum_{n=1}^{7 T}\left\{\sum_{i=1}^{n} P_{1}\left(1-P_{1}\right)^{i-1}\left(1-P_{2} P_{3}\right)^{i}\right\} D
$$

各式中で用いている変数は，以下の条件を満たすこ ととする. 地域住民の点検回数 $x$ は非負であり，0から7 の值をとる. 技術者の点検間隔 $T$ は正の整数と寸る. $P_{1}$ $P_{2}, P_{3}$ はそれぞれ0から1の值をとる。 また，以上の条件 より, 最適化問題のデザイン変数は地域住民の期待点検 回数 $x$ と技術者の点検間隔Tである.したがって，本モ デルはこの值の設定，すなわち住民と技術者の点検の分 担によって社会的費用の最小化を図るものである.

\section{4. 社会的費用のシミュレーションと考察}

$$
\text { シミュレーションの条件設定 }
$$

表-1 パラメータ

\begin{tabular}{|c|c|}
\hline ポットホール発生確率 : $P_{1}$ & 0.05 \\
\hline 地域住民の余㗇時間の価值 : C (円/回) & 1000 \\
\hline 技術者の点検費用 : $\mathrm{C}^{\prime}$ (円/回) & 10000 \\
\hline ポットホールによる期待被害額 : D (円) & 5000 \\
\hline
\end{tabular}

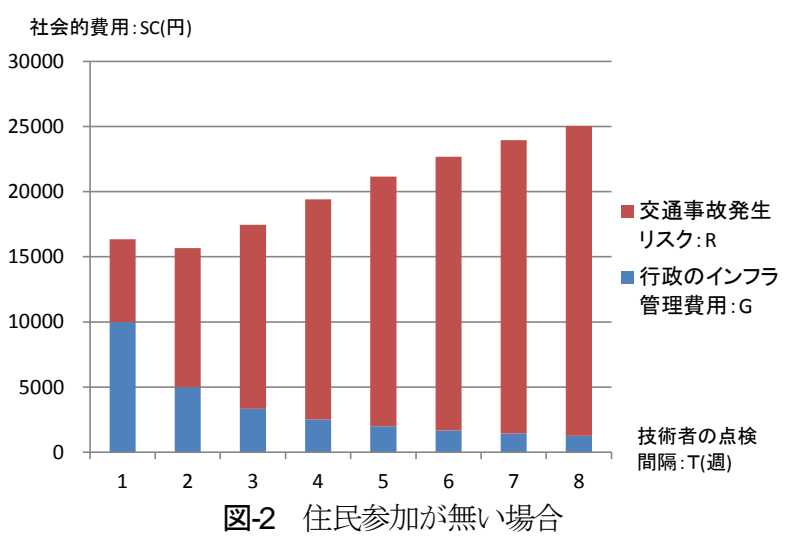

前章で構築したモデルを用いて，簡単な数值シミュレ ーションにより挙動を確認する．地域住民による点検頻 度は，住民の人数や対象となる延長といった要因によっ て決定されるものと想定する. 本研究で示したモデルは 対象となる道路の延長について考慮していないため, こ こでは週あたりの期待点検回数が既知であるとして，点 検頻度を設定值で与えられることを仮定する．与えられ た週当たりの地域住民の期待点検回数奻ら，ある1日に 地域住民による点検が行われる確率 $P_{2}$ は， $\mathrm{x}=7 P_{2}$ の関 係によって決まる.この条件により実務への展開に鑑夕 れば，ネットワークレベルで，かつ各道路区間の延長等 を考慮する必要があるが，基礎的な検討のためここでは 1単位の延長を持つ仮想の道路1区間を対象としている. ポットホールが発生する確率，及び地域住民の報告率に ついては，表-1に示すパラメータを設定して比較を行う こととした．地域住民が1回あたりの点検に供出するコ ストCは地域住民が点検を行うことによる余㗇時間の損 失，技術者の点検費用 $\mathrm{C}^{\prime}$ は点検及び補修を実施すること で発生する総費用, 期待被害額Dはポットホールが存在 することで交通事故が発生した場合の平均被害額とする. 各パラメータについては, 現段階で設定の根拠となる知 見が蓄積されていない，実務への適用にあたってはパラ メータの設定根拠が必要であり, そのための調查が必要 となる.ここではモデルの挙動を確認するための仮想的 な試算を行う。ここで得られる結果はパラメータの相対 的な関係により変動するものであり, 実社会への示唆を 与える結果を示すものではない.

\section{（2）技術者のみを考慮したケース}

技術者の点検頻度とリスクはトレードオフの関係にあ る. 地域住民の参加が全く行われないとした時, $x=0$, $P_{2}=0, P_{3}=0$ である. 技術者の点検間隔 $T$ を変数として 1 
から 8 の值をとる時の社会的費用を算出した結果を図-2 に示す．技術者の点検間隔が長くなるほど，1週間あた りの行政のインフラ管理費用は少なくなるが，ポットホ 一ルが放置されることでリスクが増大し，社会的費用は 増大寸る関係が確認できる. このケースでは，2週間に 1 回点検を行う場合に社会的費用は最小となる. リスク を低くするためにはある程度高い頻度で点検を行う必要 がある.

\section{（3）住民参加と技術者の役割分担による社会的費用の 最小化}

地域住民が点検に参加した時を想定し，社会的費用を 最小化するための住民と技術者の役割分担について，シ ミュレーションを行う.

技術者の点検間隔 $T$ が 1 から 8 , 地域住民の点検回数 $\mathrm{x}$ が0から7をとる時の社会的費用を算出した結果を図-3，

図-4に示寸. $S C$ は地域住民の報告率 $P_{3}=0.1$ の時, $(\mathrm{x}, \mathrm{T})=(0,2)$ で最小となる. これは, $P_{3}=0.1$ では地域住民 の報告率が低いため，住民参加によるリスクの縮減量が 小さく, 点検回数が増えればUが大きくなるためである. $P_{3}=0.3$ の時, $(\mathrm{x}, \mathrm{T})=(5,8)$ で最小となる. これは報告率が 大きく，地域住民による点検の効果が大きくなり，技術 者による点検の頻度が少なくなったとしても，住民によ る点検の頻度を大きくすることによってリスクを回避す るような最適解が選択されたことを示している．したが って, 報告率によって最適となる役割分担が異なること

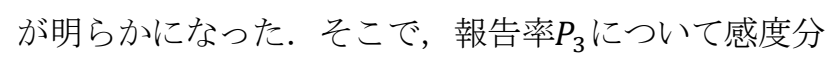
析を行った結果を表-2に示寸．これは，点検に参加する 地域住民に点検方法の講習等を行うことで, 点検の精度 が向上するような状態を想定する．地域住民の点検精度 が向上した時に得られる最適解が，どう変化するかを考 察する. 感度分析の結果, 技術者の点検頻度は $P_{3}=0.1$ の ときを除いて8回と低い頻度になっている，一方で地域 住民の報告率が向上すると, 最適となる住民の点検回数 が減少している. すなわち，地域住民の点検精度が向上 することで，より少ない点検回数で社会的費用が縮减で きることが期待できる．地域住民の報告率が上昇する要 因として, 行政が地域住民に対して講習会を開催するな ど，教育面でのサポートが考えられる．現実の地域協働 型インフラ管理における住民教育の例として, 岐阜県の

「社会基盤メンテナンスサポーター（MS）」の委嘱に おいては，講習会の受講が義務付けられている ${ }^{8)}$ ここう した講習の充実は効果的であると考えられる.

\section{（4）幹線道路と生活道路を想定した試算}

本節では, 幹線道路と生活道路の違いによる住民と専 門家の役割分担について考察する. 幹線道路か生活道路 の違いを本モデルで表現するには，ポットホールの発生

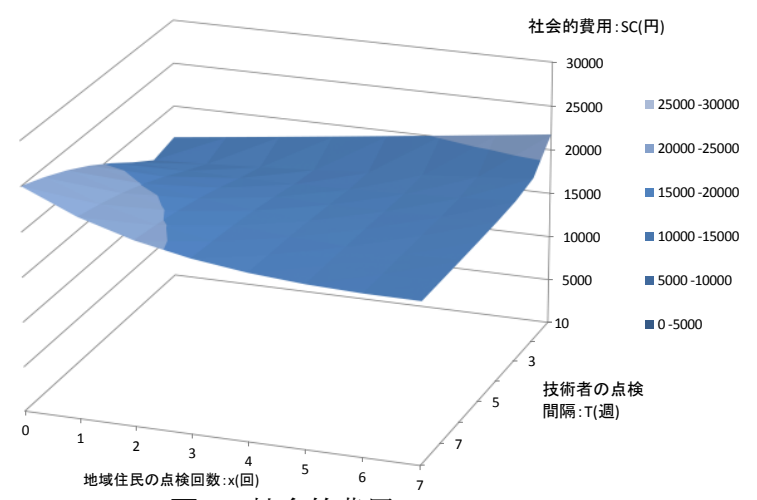

図-3 社会的費用 $(\mathrm{P} 3=0.1, \mathrm{D}=5000)$

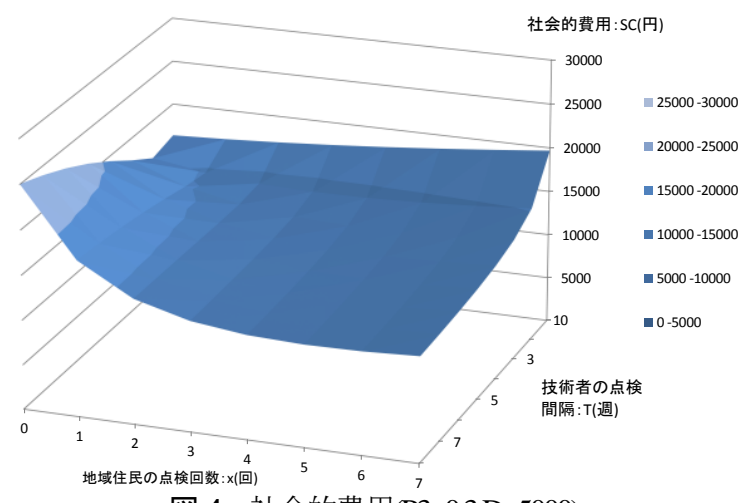

図-4 社会的費用 $(P 3=0.3, D=5000)$

表-2 報告率に関する感度分析

\begin{tabular}{|c|c|c|c|}
\hline$P_{3}$ & $\mathrm{x}$ (回) & $\mathrm{T}$ (週) & $\mathrm{SC}($ 円 $)$ \\
\hline 0.10 & 0 & 2 & 15665 \\
\hline 0.15 & 6 & 8 & 15348 \\
\hline 0.20 & 6 & 8 & 13612 \\
\hline 0.25 & 5 & 8 & 12379 \\
\hline 0.30 & 5 & 8 & 11387 \\
\hline 0.35 & 5 & 8 & 10613 \\
\hline 0.40 & 5 & 8 & 9992 \\
\hline 0.45 & 4 & 8 & 9478 \\
\hline 0.50 & 4 & 8 & 8992 \\
\hline
\end{tabular}

確率 $P_{1}$ と期待被害額 $\mathrm{D}$ に違いを持たせることが考えられ る. 本節では, ある地域内を考えた時, 道路の管理状態 が同じ程度の状況下でも, 幹線道路と生活道路で住民と 専門家の分担に違いが出ることを検証するために，ポッ

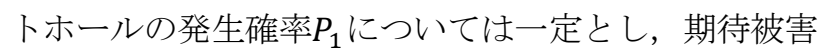
額Dに異なるパラメータを与えて検証を行うこととする。 ポットホールによる期待被害額は, 周辺の住民人数や交 通量などの要因によって変化する. 舖装の劣化状態など が同条件であっても，交通量が異なればポットホールに よる期待被害額が異なり, 最適な点検頻度は変化すると 考えられる. 前節の条件設定が生活道路のような交通量 が大きくない道路だとしたとき，ここでは交通量が大き い幹線道路を設定したケースを考える. すなわち，前節 で設定した期待被害額よりも大きい值を与えたときの結 果を比較する. ポットホールによる期待被害額を $\mathrm{D}=20000$ (円) として算出した結果を示す．地域住民 の報告率は $P_{3}=0.1, P_{3}=0.3$ の2通りで設定し, 技術 
者の点検間隔 $T$ が1から 8 , 地域住民の点検回数 $\mathrm{x}$ が0から 7をとる時の社会的費用を算出した結果を図-5，図-6に 示す．地域住民の報告率 $P_{3}=0.1$ の時， $(\mathrm{x}, \mathrm{T})=(1,1)$ に 最小となる.これは前項の図-5で示した結果 $(\mathrm{x}, \mathrm{T})=$ $(0,2)$ と比べると地域住民の回数が1多く, 技術者の点検 間隔は1少ない，期待被害額が大きくなり，技術者のみ の点検で2週間に1度の点検では残存するリスク量が相 対的に大きいため，これを減少させる必要があることが 原因である.

地域住民の報告率 $P_{3}=0.3$ の時, $(\mathrm{x}, \mathrm{T})=(7,8)$ に最小 となる．報告率が高くなれば，地域住民によるリスクの 縮減が大きくなる，そのため，期待被害額Dが高くても， 技術者の点検の頻度を小さくしてもリスクが小さくなる. 報告率 $P_{3}$ について感度分析を行った結果を表-3に示寸. 感度分析の結果から, 報告率が向上寸るにつれて, 地域 住民の点検回数は増加している. 前節の算出結果と比較 寸ると, 期待被害額が低い場合は，ある程度の報告率が 見込めるのであれば，より少ない点検回数でリスク縮减 をすることができた．期待被害額が大きい場合，地域住 民が高い精度で点検できるのであれば，より多くの住民 参加が効果的となる. 残存するリスク量自体が高くなる ので，ある程度の報告率が見込めるのであれば，地域住 民がより多く点検を行い，毎日確認を行う方が効果的と なる。

\section{5. おわりに}

地域住民が道路点検に参加する地域協働型インフラ管 理を想定した数理モデルを構築し，住民参加が行われた 場合の社会的費用について簡易的なシミュレーションを 行った. 地域住民の過度な参加は社会的費用を増大させ る可能性があること，地域住民の教育を実施することで 効果的な役割分担が期待できることを示した.

今回のシミュレーションにおいては道路延長の概念を 考慮しておらず, 1 単位の延長の道路を仮想し, 各パラ メータは仮の值を設定している，実地域を対象とした検 証を目指すため, パラメータ設定の根拠となる調査を実 施することが必要である.また，感度分析の結果から分 かるように，最適解の動きが極端なものになっており， モデルの条件設定の精査が必要である，そのためには， ポットホールの生起と点検の関係，確率の定義を厳密に するため，ポットホールと事故発生の関係について知見 の蓄積をしていくことが重要である.

今後はこれらの課題点を踏まえたうえで, 現実の地域 に適用することを目指し，ケーススタディを実施してい く必要がある.

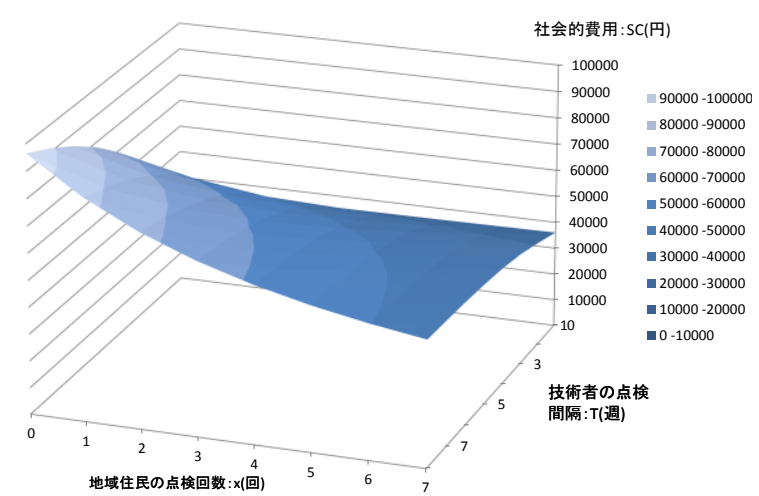

図-5 社会的費用 $(P 3=0.1, D=20000)$

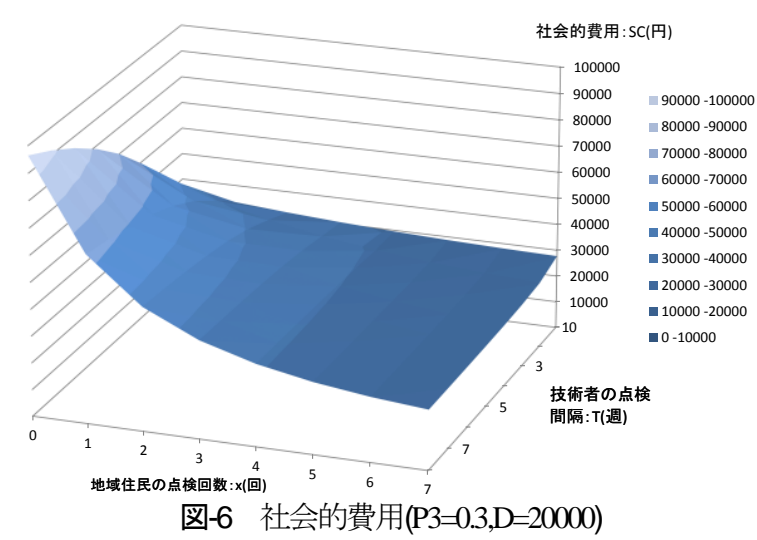

表-3 報告率に関する感度分析

\begin{tabular}{|l|l|l|r|}
\hline 0.10 & 1 & 1 & 35356 \\
\hline 0.11 & 3 & 1 & 35178 \\
\hline 0.12 & 4 & 1 & 34863 \\
\hline 0.13 & 6 & 1 & 34461 \\
\hline 0.14 & 7 & 1 & 34013 \\
\hline 0.15 & 7 & 1 & 33533 \\
\hline 0.16 & 7 & 1 & 33066 \\
\hline 0.17 & 7 & 2 & 32418 \\
\hline 0.18 & 7 & 2 & 31632 \\
\hline 0.19 & 7 & 2 & 30883 \\
\hline 0.20 & 7 & 3 & 30169 \\
\hline 0.21 & 7 & 8 & 29224 \\
\hline 0.25 & 7 & 8 & 25703 \\
\hline 0.30 & 7 & 8 & 22358 \\
\hline 0.35 & 7 & 8 & 19803 \\
\hline 0.40 & 7 & 8 & 17786 \\
\hline 0.45 & 7 & 8 & 16155 \\
\hline 0.50 & 7 & 8 & 14809 \\
\hline
\end{tabular}

謝辞 : 本研究の一部は, 平成26年度学術研究助成基金助成金 (基盤研究 (B), 課題番号 : 26289173, 研究課題名 : 民産官 学連携による地域協働型インフラ管理システムの実装可能性と 有効性検証, 研究代表者 : 岐阜大学高木朗義教授）によるもの である。 


\section{参考文献}

1) 国土交通省 : インフラ長寿命化計画(行動計画), 2014

2) 大野沙知子：地域協働型道路施設管理を目指した仕組み づくりと人づくりのあり方に関する研究，土木学会論文 集.F4, vol.67, No.4, I_145-I_158, 2011.

3）大野沙知子，高木朗義 : 地域協働によるインフラストラ クチャー管理の要件岐阜県中津川市を事例に-, 土木学会 論文集 F4(建設マネジメント)，vol.69，No.4，I_121-I_128， 2013.

4) 貝戸清之, 小林潔司, 加藤俊昌, 生田紀子 : 道路施設 の巡回頻度と障害物発生リスク, 土木学会論文集 F, vol.63, No.1, 16-34, 2007.

5) 小濱健吾, 貝戸清之, 小林潔司 : 苦情発生を考慮した道 路巡回政策，土木学会論文集 F4(建設マネジメント), vol.70, No.1, p.25-37, 2014.

6) 長崎大学大学院工学研究科 工学部インフラ長寿命化セ ンター平成 26年度活動報告書, 2015 .

7）岐阜県 HP，住民との協㗢

http://www.pref.gifu.lg.jp/kendo/michi-kawa-sabo/doroij/jumin-tono- kyodo/(閲覧日:2015 年 8 月 31 日)

8) 社会基盤メンテナンスサポーター事業実施要領(平成 25 年 6 月 1 日改正).

9) 岩城一郎：”ふくしま発”市民とともに道を造り，橋 を守る!, セメント・コンクリート，No.790，p.9-14, 2012.

10) 〜「ふくしま発」市民との協働による橋守\&みちづ くり事業〜, コンクリートテクノ, vol.31, No.7, p.25-27, Jul.2012.

11) FixMyStreet Japan, https://www.fixmystreet.jp/ (閲覧日:2015年 8 月 31 日)

12) 半田市ホームページ,「マイレポはんだ」とは http://www.city.handa.lg.jp/kikaku/shise/kocho/myreport/ myrepohanda.html(閲覽日:2015 年 8 月 31 日)

(2015.5.18 受付)

\section{SOCIAL COST ANALYSIS FOR COOPERATIVE ROAD FACILITIES MANAGEMENT IN THE LIGHTING OF THE ROLE OF RESIDENTS AND EXPERTS}

\section{Takayuki TOMIDA, Sachiko OHNO, Satoshi SUGIURA and Akiyoshi TAKAGI}

In the current economy, it is impossible for local municipalities in Japan to maintain all public facilities in good condition. Under these circumstances, it may be more efficient to encourage residents to support maintenance efforts, such as by engaging in daily monitoring. For these reasons, a system of "cooperative road-facility management" whereby road facilities are maintained by various stakeholders including local municipalities, private companies, and residents are proposed. To this end, this paper addresses the subject of resident partnerships involving experts and residents. More specifically, this paper considers the ideal approach for cooperative road-facility management by focusing on social cost analysis. In this model, resident's cost, expert's cost and risk is identified. This paper tends to analysis some cases. As a result, the prospect of the road facilities management is shown by the role of the residents and the cooperative between residents and experts. 